\title{
O PODER DISCIPLINAR E A PRODUÇÃO DA DELINQUÊNCIA EM MICHEL FOUCAULT
}

\begin{abstract}
Marcele Homrich Ravasio
Autora correspondente. Instituto Federal Farroupilha. Rodovia RS-218 - Indubrás. Santo Ângelo/RS, Brasil. CEP 98806-700. http://lattes.cnpq.br/8085073893881510. https://orcid.org/0000-0003-0162-1426. marcele.ravasio@iffarroupilha.edu.br
\end{abstract}

\section{Alena Ocom Moreira}

Universidade Católica do Rio Grande do Sul - PUCRS. http://lattes.cnpq.br/3884627439171085. https://orcid.org/0000-0001-7633-4486. alenaocommoreira@gmail.com

\section{Tainah Motta Nascimento}

Universidade Federal do Rio Grande do Sul - UFRGS. http://lattes.cnpq.br/9362321257824240. https://orcid.org/0000-0002-8327-3930. tainahmottanascimento@gmail.com

Valendo-se do método hipotético-dedutivo e da pesquisa bibliográfica, este trabalho parte das contribuições do filósofo francês Michel Foucault acerca da delinquência e das formas pelas quais ela é produzida no sistema penitenciário. Para tanto, parte-se dos modos de poder teorizados pelo autor. As técnicas, que possuem como objetivo uma espécie de treinamento ortopédico dos corpos, são denominadas poder disciplinar. A disciplina, compreendida como um instrumento que permite o controle maciço dos corpos, responsável pela sujeição das potencialidades, contribui para que sejam úteis de algum modo. Nesse sentido, o sistema penitenciário, a prisão, serve como aplicação das decisões dos magistrados e também possui como escopo a inserção permanentemente no detento de um conhecimento que vai transformar uma medida penal em um procedimento penitenciário, fazendo da pena do criminoso uma maneira de modificá-lo, para que, mesmo assim, ele tenha utilidade para a sociedade. O sistema penal, com todos os seus instrumentos de controle, e, principalmente, a prisão em sua essência, fabrica uma classe diferenciada de pessoas. A prisão não exerce seu papel de correção e, consequentemente, convoca esses indivíduos ao retorno. Assim, a prisão dispõe da vantagem de produzir a delinquência, que foi, e ainda é, um instrumento de opressão social, direcionada indubitavelmente a uma classe distinta da sociedade.

Palavras-chave: delinquência; poder disciplinar; adestramento; Michel Foucault.

\section{THE DISCIPLINARY POWER AND THE PRODUCTION OF DELINQUENCY IN MICHEL FOUCAULT} ABSTRACT

Through the deductive-hypothetic method and bibliographical research, the present work starts from the contributions of the French philosopher Michel Foucault, with the aim to comprehend the production of delinquency by the prison system starting from the power prioritized by the author. Thus, the techniques that have as aim a kind of orthopaedic training of the bodies are called disciplinary power. Discipline is understood as an instrument that allows massive control of bodies responsible for the subjection of potentialities, which contributes to their usefulness in some way. In this sense, the penitentiary system, the prison serves only as an application of magistrates' decisions, but also has as its scope the permanent insertion in the custody of a knowledge that will transform a penal measure into a penitentiary procedure, making the sentence of the criminal a way of changing it, so that it may still be useful to society. The penal system with all its instruments of control, and especially the imprisonment in its essence, make a differentiated class of people, where the prison does not exercise its correcting role, and consequently summons these individuals to return. Thus, imprisonment produces delinquency, which was, and still is, an instrument of social oppression, undoubtedly directed at a distinct class of society.

Keywords: delinquency; disciplinary power; training; Michel Foucault.

Recebido em: 4/12/2017

Aceito em: $21 / 10 / 2020$ 


\section{Humanos e \\ Democracia}

\section{INTRODUÇÃO}

No decorrer dos anos 1970, Foucault direcionou suas pesquisas para a problemática do poder, impulsionado cotidianamente por uma enorme vontade de saber, aliada a uma curiosidade que o conduziu a diferentes assuntos e domínios. Ao longo de suas obras fez exames minuciosos dos dispositivos de poder relativos, por exemplo, à Medicina, à prisão, à história da loucura, à Justiça e também ao Direito. É necessário deixar claro, entretanto, que Foucault sugeriu em suas obras que o poder não está situado em um lugar específico da estrutura social; ele funciona por meio de mecanismos - dispositivos aos quais ninguém do corpo social consegue escapar. É nesse contexto que surge a polêmica de que o poder não é uma propriedade, na medida em que não existe um lado dos que se encontram protegidos por ele.

Na realidade, o que existe são as relações de poder, os seus dispositivos dentro do corpo social, ou seja, o poder é algo que funciona, que se efetua; não é um objeto, uma coisa, é uma relação que se estrutura principalmente em relações de força. $O$ estudo de Foucault procurou esclarecer a conclusão, do seu ponto de vista equivocada, de que o poder está centralizado em um só lugar, desconstruindo a ideia de que o lugar central e único do poder está no Estado e de que as redes de poder da sociedade são efeitos estatais.

Esse poder assumiu as formas mais concretas, invadindo o que há de mais material no indivíduo: o seu corpo, no nível de corpo social, que penetra no cotidiano, chamado de micropoder ou subpoder. Foucault caracterizou a Microfísica do Poder como sendo as técnicas minuciosas de controle do corpo, uma investigação dos procedimentos técnicos, ou seja, um controle dos "gestos, atitudes, comportamentos, hábitos, discursos" (FOUCAULT, 2014a, p. 14).

É necessário parar de caracterizar o poder negativamente, na forma de repreensão, e não apenas reduzir sua função à exclusão dos corpos, embora ele realmente produza isso, mas entender que o poder é mais que opressões, e que esse não é o seu real fundamento; existe um lado positivo nele, que é a produção de verdades. O poder possui uma grande estratégia; ele tem um objetivo que é o corpo humano, não para fazê-lo passar pelo suplício, mas, pelo contrário, para torná-lo corpo dócil e adestrado. Nesse sentido, parece fazer mais sentido sustentar a ideia de que "[...] o que faz com que o poder se mantenha e que seja aceito é simplesmente que ele não pesa só como a força que diz não, mas que de fato ele permeia, produz coisas, induz ao prazer, forma saber, produz discurso" (FOUCAULT, 1990, p. 8).

O objetivo básico das relações de poder não é retirar os indivíduos do corpo social, mas, sim, controlar suas vidas, administrá-las, adestrá-las, com o intuito de utilizar o máximo possível o seu potencial e sua força de trabalho, pondo fim às revoltas populares; "tornar os homens dóceis politicamente" (FOUCAULT, 2014a, p. 20). Michel Foucault iniciou suas pesquisas sobre o poder quando continuava os estudos sobre a história da penalidade, e no transcorrer desses estudos surgiu o problema correlacionado ao poder "sobre os indivíduos enclausurados que incidia sobre seus corpos e utilizava uma tecnologia própria de controle" (FOUCAULT, 2014a, p. 21).

A base das relações de poder é a revolta. Sem a liberdade não há como haver poder. É preciso um confronto entre as forças sociais, existir uma insurgência por parte dos que estão submetidos às relações de poder. Há, por parte de Foucault, algumas características com relação ao poder que devem ser enfatizadas, dentre as quais é possível citar a questão do poder 


\section{Humanos e \\ Democracia}

disciplinar, que é o centro de toda a sua pesquisa de 1973 a 1975; o biopoder, que foi problematizado entre 1976 e 1977; e, por fim, a governabilidade a partir de 1978.

Na década de 70 do século 20 houve uma modificação da noção de poder em Michel Foucault, na medida em que ele aprofunda suas pesquisas em torno do poder na Civilização Ocidental. É possível observar as diversas estruturas que fizeram funcionar as relações de poder e possibilitaram a criação e o estudo de diferentes categorias de poder. Assim, no percurso da pesquisa destacaram-se as três categorias supracitadas, que coexistem em determinados setores da sociedade ocidental a partir do século 16.

As pesquisas traçam a trajetória do poder desde o século 16 no Ocidente até o momento em que envolve o homem contemporâneo. Foucault caracterizou de biopoder, e também de genealogia do poder, as várias práticas de poder sobre o corpo onde estas terão o corpo como seu principal objeto. "A genealogia [...] está, portanto, no ponto de articulação do corpo com a história. Ela deve mostrar o corpo inteiramente marcado, e a história arruinando o corpo" (FOUCAULT, 1990, p. 22).

Foucault dividiu o poder em duas redes de exercícios. De um lado as técnicas que têm como objetivo fazer uma espécie de treinamento ortopédico dos corpos, com o poder disciplinar; de outro, o corpo como integrante de uma categoria e a população com suas normas e regulamentos. Com a publicação de seu livro História da Sexualidade I: a vontade de saber, o enfoque foi centrado para o corpo molar da população, sugerindo o biopoder.

O que realmente interessou para Foucault foi à análise das técnicas e dispositivos utilizados pelo poder e como alguns desses mecanismos permanecem até hoje em nossos corpos. Dentre esses mecanismos está a disciplina; "esses métodos que permitem o controle minucioso das operações do corpo, que realizam a sujeição constante de suas forças e lhes impõe uma relação de docilidade-utilidade" (FOUCAULT, 1990, p. 126). Aqui, o poder que se encontra na anatomia do indivíduo é denominado biopoder.

Sucedendo o biopoder, surgiu o poder disciplinar, que alcançou seu pleno desenvolvimento apenas no século 18. Esse poder é uma tecnologia que se sustenta no corpo do indivíduo, mas, principalmente, em seus atos. Foi nesse momento histórico que se colocou em prática o mecanismo pelo qual extraia o tempo, que conseguia utilizar todo o potencial que o indivíduo tinha para o trabalho. Nas palavras de Roberto Machado (1988, p. 194), "[...] nem é um aparelho, nem uma instituição: ela funciona como uma rede que atravessa sem se limitar as suas fronteiras; é uma técnica, um dispositivo, um mecanismo, um instrumento de poder".

Essa modalidade de poder tem alguns princípios básicos, tais como a distribuição espacial dos indivíduos, que não exerce um controle sobre os resultados das ações, mas, sim, de seus desenvolvimentos, e, por fim, é uma técnica que necessita de vigilância constante dos indivíduos. Foucault faz uma análise do poder disciplinar com o biopoder, sem abandonar nem o primeiro tampoco o segundo, de modo que eles se articulam, formando ideias para a governabilidade.

Surge, então, um novo objeto de articulação do poder: a população. As taxas de mortalidade, natalidade, longevidade, contribuíram para a formação de uma nova tecnologia do poder. É nesse ponto que entra a fusão entre o poder disciplinar e o biopoder; um novo modo de gerir o corpo social e um novo objetivo de análise do poder, que "se situa e exerce ao nível 


\section{Democracia}

Humanos e

da vida, da espécie, da raça e dos fenômenos maciços de população" (FOUCAULT, 1990, p. 129). Não há confirmação, por parte Foucault, de que foi realmente no século 18 que a população passou a ser vista como um objeto de atuação do poder.

Já, no entanto, na Antiguidade, em Roma, era possível visualizar a existência de políticas públicas que visavam a uma regulamentação da população, mas foi apenas no século das luzes que a população começou a ser estudada com afinco, surgindo várias políticas baseadas nas ciências dos homens, como a criação da medicina social, objetivando a higiene corporal contra doenças e pestes.

Com essas políticas ocorria o controle maciço da população, diferenciando-se das antigas políticas que eram negligentes com os indivíduos. Assim aduz o autor:

[...] qual é a base para esta transformação? Genericamente, pode-se dizer que ela se relaciona com a preservação e conservação da "força de trabalho". Mas, indubitavelmente, o problema é mais amplo. Ele indiscutivelmente se refere aos efeitos político-econômico da acumulação de homens (FOUCAULT, 1990, p. 171).

O que o autor quer dizer é que, em razão do numeroso crescimento demográfico do século 18 na Europa Ocidental, houve uma necessidade do Estado de utilizar mecanismos de controle mais eficazes e adequados, proporcionando um novo cálculo da tecnologia populacional, com pirâmides etárias, estudos com relação ao crescimento ou não da população e os números de casamentos e procriações. É preciso entender que governo não é um grupo de pessoas que têm a gestão das políticas públicas ou quem conduz o Estado, mas, sim, como aduziu Foucault no século 16,

[...] governo não se referia apenas a estruturas políticas ou administrativas dos Estados; antes, designava o modo pelo qual a condução de indivíduos ou grupos deveria ser orientada: o governo das crianças das almas, dos bens, das famílias, dos doentes (FOUCAULT, 1990, p. 221).

Nos séculos 17 e 18 foi necessário uma arte de governar voltada para o Estado; um governo produzido pelo Estado moderno, pois só nesse momento aparece, nos estudos de Foucault, a vontade de explicar o Estado como sendo um conjunto de práticas que tem a população como objeto, na economia e em dispositivos de segurança, prática denominada por Foucault de governabilidade. Uma arte de governar na modernidade; "de uma nova razão governamental no sentido de um governo racional capaz de conhecer e aumentar a potência do Estado" (FOUCAULT, 2014a, p. 31-32).

Na metade do século 18 colocou-se em pauta o problema de uma unificação do poder urbano. Percebeu-se a necessidade de que, pelo menos nos grandes centros urbanos, fosse feita uma organização do corpo urbano de um modo homogêneo e bem regulamentado. Um dos motivos é que a cidade não é apenas um lugar das indústrias/mercado, mas, sim, de produção, e essa vem dos indivíduos, necessitando, assim, de mecanismos que regulamentem, da melhor forma possível, o trabalho, para extrair todo o seu potencial. O outro motivo é político;

[...] o aparecimento de uma população operária pobre que vai tornar-se, no século XIX, o proletariado, aumentará as tensões políticas no interior da cidade. As relações entre diferentes pequenos grupos, que se opunham uns aos outros, mas se equilibravam e se 


\section{Democracia}

Humanos e

neutralizavam, começam a se simplificar em uma espécie de afrontamento entre rico e pobre, plebe e burguês, que se manifesta através de agitações e sublevações urbanas cada vez mais numerosas e frequentes (p. 153).

É nesse cenário que as revoltas urbanas começam a ocorrer, especialmente pela plebe em vias de se proletarizar. Surge, então, essa preocupação de haver um poder político que seja capaz de analisar e enquadrar a população urbana. A medicina é um dos mecanismos que surgem nesse sentido; um meio político, como exclusão, como meio de purificação do espaço urbano, pois medicalizar um dos indivíduos era a mesma coisa que purificar o restante da população. Na mesma direção temos a exclusão dos loucos e dos delinquentes, como um modo de tirar do convívio da população quem não era útil para a sociedade/Estado.

\section{A DELINQUÊNCIA EM MICHEL FOUCAULT}

No ano de 1955, Lévi-Strauss escreveu em um trecho de seu livro Tristes trópicos que as sociedades descobriram dois meios de excluir um indivíduo perigoso: a primeira maneira é incorporar toda essa energia do indivíduo para aniquilar tudo de perigoso que possa haver nela, é a solução antropofágica; e a outra forma é tentar derrotar a adversidade dessa força, acabando com o que tiver de energia nela, ou seja, é a forma contrária da primeira maneira, é vencer essa energia para obter o seu controle; essa prática é chamada, pelo autor, de antropoemia.

Foucault, por um tempo, utilizou-se dessa definição de exclusão em suas obras. Com efeito,

[...] ela serviu para caracterizar, designar de modo bastante vago o estatuto conferido, numa sociedade como a nossa, a delinquentes, minorias étnicas, religiosas e sexuais, a doentes mentais, a indivíduos que ficam fora dos circuitos de produção ou consumo, enfim a todos aqueles que possam ser considerados anormais ou desviantes. Não acredito que essa noção tenha sido inútil; em dado momento, ela pôde exercer uma função crítica útil, visto que se tratava de reverter as noções psicológicas, sociológicas ou psicossociológicas que tinham invadido o campo das ciências humanas, tais como as de desvio, inadaptação e anomalia, cujo conteúdo psicológico ocultava uma função bem precisa: mascarar as técnicas, os procedimentos e os aparatos com os quais a sociedade excluía alguns indivíduos, para apresentá-los em seguida como anormais, desviantes (FOUCAULT, 2015, p. 4).

Para uma análise mais profunda do assunto, porém, essa definição é insuficiente, posto que a noção de exclusão nos mostra o indivíduo excluído das representações sociais; "ele já não se comunica com os outros no nível do sistema de representações, e é por isso que se mostra, precisamente, desviante" (FOUCAULT, 2015, p. 4-5). Foucault explica, também, que essa definição de exclusão de Lévi-Strauss oportuniza responsabilizar toda a sociedade pelo dispositivo que faz com que o excluído seja excluído, ou seja,

[...] perde-se não só o mecanismo histórico, político, de poder, como também se corre o risco de ser induzido em erro no que se refere à instância que exclui, pois a exclusão [parece] referir-se a algo como um consenso social que rejeita, ao passo que por trás disso talvez haja várias instâncias perfeitamente especificadas, por conseguinte definíveis, de poder que são responsáveis pelo mecanismo de exclusão (FOUCAULT, 2015, p. 5). 


\section{Democracia}

Humanos e

Neste mesmo período a noção de transgressão teve quase o mesmo papel que a noção de exclusão; elas tiveram um papel histórico muito importante, mas, na concepção de Foucault, agora elas devem seguir um novo rumo; "já não se falará em lei, regra, representação, mas em poder em vez de lei, em saber em vez de representação" (FOUCAULT, 2015, p. 7).

Lévi-Strauss ainda faz uma análise do desenvolvimento histórico das táticas punitivas, que são quatro grandes táticas de sanção que se desenvolveram ao longo dos séculos. A primeira ele chamou de excluir, que se refere à proibição de um indivíduo em lugares públicos e sagrados, proibindo todas as regras de cordialidade; "trata-se de privá-lo de sua casa, suprimir até a realidade de seu lar" (FOUCAULT, 2015, p. 7). A segunda tática era organizar um ressarcimento, impor uma compensação; nesse caso, com a infração da regra ocorrem dois procedimentos: em um a vítima do dano pode exigir a reparação, e, por outro lado, desencadeará algumas obrigações para o infrator; "o objetivo é prender o infrator dentro de uma rede de obrigações multiplicadas, exacerbadas em relação à rede tradicional na qual ele se encontra" (FOUCAULT, 2015, p. 8).

Temos como terceira sanção a marcação (marcar), ou seja, é fazer um sinal no corpo, fazer com que esse corpo seja diminuído, nem que essa marca seja simbólica; estabelecer de qualquer forma a humilhação nesse corpo; "ao poder que impôs a pena e, com essa pena, deixou no corpo do suplicado a marca de sua soberania. Na cicatriz ou amputação, visível não apenas a culpa, mas também o soberano" (FOUCAULT, 2015, p. 9). Por último, encarcerar, prática que foi definitiva na virada do século 18 para o 19.

O desempenho da marcação como punição é um trabalho com o corpo; uma maneira específica de gravar o poder no corpo do infrator e uma forma também de colocar no corpo do espectador a memória da culpa:

Se do fim da Idade Média ao século XVIII assistimos a uma variedade tão luxuriante de suplícios, é porque, precisamente, era necessário levar em conta toda uma série de variáveis: por exemplo, o status do culpado, e assim temos a decapitação, que é a morte marcada pelo selo do nobre, e a forca, morte que marcará o camponês. Têm-se a fogueira para o herege, o esquartejamento para os traidores, o desorelhamento para os ladrões, o furo da língua para os blasfemadores (FOUCAULT, 2015, p. 11).

Tudo isso funcionou até nos devaneios do tempo. A execução de Damiens, em 1757, foi o último grande confronto entre o rei e o povo, e foi nesse momento que o rei mostrou o que era capaz de fazer com o corpo de um indivíduo ao encontrar a morte no sistema penal, o qual é um sistema de reclusão e porque agora ele não desempenha um papel de marca do poder no corpo do indivíduo, mas, sim, é uma forma de reclusão redobrada, uma reclusão definitiva. A morte, agora, é a reclusão definitiva e mais segura do corpo. Foucault quis explicar essas quatro táticas de punição com a intenção de esclarecer a seguinte questão:

[...] que formas de poder são efetivamente exercidas para que, às infrações que põem em xeque suas leis, suas regras, seu exercício, ele responda com táticas como a exclusão, a marca, o ressarcimento ou a reclusão? Se me apego a essas táticas, e principalmente à reclusão, não é para tentar reconstituir o conjunto das representações jurídicas e morais que supostamente sustentam e justificam essas práticas penais; é por querer definir a partir daí as relações de poder efetivamente em ação através dessas táticas. Em outras 


\section{Democracia}

Humanos e

palavras, gostaria de abordar essas táticas como analisador das relações de poder, e não como reveladores de uma ideologia. O sistema penal como analisador de poder (FOUCAULT, 2015, p. 12-13).

De acordo com o autor, para fazer uma análise do sistema penal é necessário averiguar a origem das lutas na sociedade e verificar como elas se desenrolaram com relação ao poder. Então, se as táticas de punição são analisadoras das relações de poder, o elemento primordial é a luta política em torno do poder contra ele. "Aí está todo o jogo de conflitos, de lutas existentes entre o poder tal como exercido numa sociedade e os indivíduos ou grupos que, de uma maneira ou de outra, procuram escapar desse poder, que o contestam local ou globalmente" (FOUCAULT, 2015, p. 13).

Para Foucault, é preciso colocar no centro das análises do sistema penal a chamada guerra civil, e no seu entendimento com ela é possível entender essas táticas de lutas; ela é a fonte de todas as lutas pelo poder, como também a favor do poder e contra ele; é o que possibilita compreender o funcionamento do mecanismo da penalidade: a reclusão.

O período que será analisado é de 1825 a 1848, quando foi instaurado o funcionamento do grande sistema penal. Neste momento está em andamento a guerra social, ou seja, não é a guerra de todos contra todos, mas, sim, a guerra de ricos contra pobres, dos que são proprietários contra os que nada possuem, dos patrões contra os empregados. Então, é necessário adotar como ponto de partida para as táticas penais a guerra civil. É possível averiguar nos discursos da época "que as leis sociais são feitas por pessoas às quais elas não se destinam, mas para serem aplicadas àqueles que não a fizeram" (FOUCAULT, 2015, p. 22).

Deste modo, em 23 de novembro de 1831, em uma intervenção na Câmara no momento em que se debatia a criação de circunstâncias atenuantes no Código Penal, o deputado M. Bernard (1831, p. 5) do Departamento do Var afirmou:

[...] as leis penais, destinadas em grande parte a uma classe da sociedade, são feitas por outra. Admito que elas afetam a sociedade inteira; nenhum homem tem a certeza de sempre escapar ao seu rigor; contudo, é verdade que quase a totalidade dos delitos, sobretudo de certos delitos, é cometida pela parte da sociedade à qual o legislador não pertence. Ora, essa parte difere quase inteiramente da outra em espírito, costumes e em toda a sua maneira de ser. Portanto, para fazer leis que lhe conviessem, o legislador deveria, antes de tudo, parece-me, tentar esquecer o que ele mesmo é, [...] buscar com atenção não o efeito de determinada disposição da lei sobre ele mesmo, mas sobre o espírito do povo para o qual ele trabalha, que tem disposições bem diferentes (apud FOUCAULT, 2015, p. 22).

Outro ponto importante é o princípio da vigilância universal, que já é tratada desde 1827, ou seja, uma civilização/arquitetura do espetáculo na qual encontram-se várias pessoas reunidas em torno de alguma coisa, em que todos os olhares são destinados a uma só coisa e é exatamente isso que ocorre na era moderna: a transformação do espetáculo em vigilância. Nesse ínterim, "toda uma disposição de espírito em geral, tal que, a partir daí, os homens serão oferecidos como espetáculo a um pequeno número de pessoas, em última análise a um único homem destinado a vigiá-los" (FOUCAULT, 2015, p. 22-23). O próximo elemento é a reclusão, o aprisionamento, quando a vigilância era ainda mais importante para o seu funcionamento pleno. 


\section{Humanos e \\ Democracia}

Primeiramente, é preciso diferenciar a guerra de todos contra todos da guerra civil. $\mathrm{O}$ aumento do poder faz os indivíduos entrarem em um sistema de marcas para compor nas relações entre os homens, ou seja, uma vontade de impor respeito perante o outro. Hobbes chamou isso de "glória"; a rivalidade que constitui a guerra de todos contra todos é uma consequência necessária das paixões dos indivíduos, e apenas com o surgimento de um soberano vai conseguir pôr um fim nessa rivalidade de todos contra todos. "É preciso que tenha havido esse processo por meio do qual os poderes de todos os indivíduos sejam transferidos para um único indivíduo ou para uma assembléia e todas as vontades se reduzam a uma única vontade" (FOUCAULT, 2015, p. 26-27). A guerra apenas termina quando ocorre essa transferência de poder para o soberano.

A guerra civil é, então, o término da dissolução do soberano, ou seja, enquanto a guerra de todos contra todos somente acaba com o aparecimento do soberano, a guerra civil só poderá reaparecer quando todo esse sistema terminar, quando o soberano sumir. A realidade é que,

[...] não há guerra civil que não seja confronto de elementos coletivos: parentes, clientelas, religiões, etnias, comunidades linguísticas, classes etc. É sempre por meio de massas, por meio de elementos coletivos e plurais que a guerra civil nasce, se desenrola e se exerce. Portanto, ela não tem em absoluto a dimensão natural das relações entre indivíduos na qualidade de indivíduos: os atores da guerra civil são sempre grupos na qualidade de grupos (FOUCAULT, 2015, p. 27).

A guerra civil é formada por personagens coletivos e faz com que ainda mais apareçam novos personagens coletivos; além disso, ao contrário do que a teoria política afirma, a guerra civil não aparece antes do poder e muito menos é aquilo que marca o desaparecimento dele. Ela não está em um vínculo de exclusão com o poder; pelo contrário, a guerra civil tem seu pleno desenvolvimento no poder. Dentro dele "não há guerra civil a não ser no elemento do poder político constituído; ela se desenrola para manter ou para conquistar o poder, para confiscá-lo ou transformá-lo" (FOUCAULT, 2015, p. 28), ou seja, quando ocorre um movimento de revolta não tem a destruição de elementos de poder, mas, sim, o apoderamento deles para colocar em funcionamento, entretanto com outro objetivo:

Guerra civil é, ao contrário, aquilo que assombra o poder: assombrar não no sentido de causar medo, mas no de que a guerra civil habita, permeia, anima e investe o poder integralmente. Encontram-se os signos disso na forma de vigilância, da ameaça, da posse da força armada, enfim, de todos os instrumentos de coerção que o poder efetivamente estabelecido adota para exercer-se (FOUCAULT, 2015, p. 30).

Em meio à guerra civil e a esses movimentos coletivos, surge, no século 18 , a posição do criminoso, mas com a concepção de que o crime não é apenas uma culpa, aquela que causa algum prejuízo a alguém, mas, sim, aquilo que prejudica a sociedade como um todo, ou seja, nesse período histórico o criminoso começou a ser visto como aquele que rompe com o pacto social e entra em guerra contra a sua própria sociedade. $\mathrm{O}$ crime é aquilo que reacende de forma precária a guerra de todos contra todos, ou melhor, de um sujeito contra o resto.

O criminoso é, então, o inimigo social, o estranho, mas não como externo. Dessa forma, a punição não deveria ser o ressarcimento desse prejuízo e nem um castigo; pelo contrário, a sociedade deve instalar uma contraguerra contra o inimigo da sociedade e, assim, constitui-se 


\section{Democracia}

Humanos e

a noção de pena, que não ocorre pelo tamanho da culpa ou o prejuízo causado, mas pelo que é útil para a sociedade; é de máxima importância para ela que os seus inimigos sejam domados e que não se multipliquem e, para isso, é necessário apossar-se deles. Já asseverava Paley (1785, p. 526) na Inglaterra: "Se a punição do delinquente não fosse perigosa para a sociedade, não haveria nenhuma razão para punir" (apud FOUCAULT, 2015, p. 32).

Desde a Idade Média começou a nascer com as instituições a chamada ação penal, isto é, um crime poderia ser movido pelas autoridades, um processo pelos representantes da sociedade, independentemente de queixa feita pela vítima; essa ação veio para substituir a vingança. A ação pública apenas era efetivada pelo procurador ou advogado do rei, porque, desde a Idade Média,

[...] o soberano já não aparece na cena da justiça simplesmente como justiceiro supremo, aquele ao qual, em última instância, se pode recorrer, mas sim como responsável pela ordem, cuja autoridade foi lesada precisamente pela desordem ou pelo crime e que, como soberano lesado, pode apresentar-se como acusador. Assim, na prática penal, fazia muito tempo que o soberano substituía o adversário singular do criminoso e vinha colocar-se diante deste. E, em nome da ordem e da paz que ele supostamente deve fazer reinar, vem declarar que o criminoso o atingiu pelo simples fato de ter-se posto num estado de guerra "selvagem" com um indivíduo, atacando-o independentemente das leis (FOUCAULT, 2015, p. 32).

No fim do século 18 surgiram várias instituição que fizeram com que o criminoso fosse efetivamente constituído como inimigo social, ou seja, mecanismos que sustentaram a ação pública para que ela não fosse apenas privada, mas eficaz. Instituições do Ministério Público, polícia judiciária, o júri, que vimos funcionando no século 19, marcaram o momento em que a sociedade teve o direito de julgar o criminoso ou de julgar por seus representantes, ou meIhor, ele não era julgado por árbitros, mas, sim, pela sociedade.

Nesse momento surgiu a possibilidade de uma percepção psicopatológica ou psiquiátrica do criminoso, alguém inflexível à sociedade,

[...] incapaz de adaptação social, que vive uma relação de agressividade constante com a sociedade, sendo estranho a suas normas e a seus valores. Em torno do fenômeno da criminalidade nascerão discursos e instituições como os que se organizam com o nome de psicopatologia do desvio. Haverá [também], nesses efeitos epistêmicos, a possibilidade de análise pela própria sociedade da produção de seus inimigos: como pode ocorrer que uma sociedade chegue a certo grau de crime, de decomposição tal que produza em grande quantidade pessoas inimigas suas? Percebe-se aí como se situa, como se fixa a possibilidade de uma sociologia da criminalidade como patologia social. Essa espécie de conector que constitui o criminoso como inimigo social é na realidade um instrumento por meio do qual a classe que está no poder transfere para a sociedade, na forma de júri, ou para a consciência social, por todas essas intermediações epistêmicas, a função de rejeitar o criminoso. Essa exclusão, que eu dizia não considerar função fundamental, é aquilo que a classe que está no poder quer que aqueles para os quais ela aparentemente transferiu a função de julgar ou castigar façam em seus atos ou em sua consciência (FOUCAULT, 2015, p. 34).

As primeiras análises econômicas da delinquência ocorreram na segunda metade do século 18 entre os fisiocratas, que eram os economistas da época, um grupo de pessoas a favor do livre-câmbio, da liberdade de comércio e de grãos e, principalmente, do liberalismo econômico, de modo que queriam um reino da ordem natural. Foucault (2015) declara que 


\section{Democracia}

Humanos e

[...] o que essa análise tem de especial é que fixa a posição, o papel e a função da delinquência, não em relação ao consumo, à massa de bens disponíveis, mas em relação aos mecanismos e processos de produção; por outro lado, no exato momento em que os fisiocratas definem o delinquente [pelo ângulo da] produção, também o caracterizam como inimigo da sociedade: é a própria posição do delinquente relativamente à produção que o define como inimigo público (p. 43).

Um dos primeiros a fornecer esse tipo de análise foi Le Trosne, no texto Mémoire sur lês vagabonds et sur lês mendiants, em 1764. Ele afirma que a vagabundagem é o elemento que faz com que os outros tipos de crimes surjam; ela é a matriz do crime que mantém todas as outras configurações de delinquência. Essa análise de Le Trosne, porém, vai de contramão a duas análises tradicionais da época. A primeira traz que a ociosidade é a mãe de todos os vícios, ou seja, de todos os crimes, "a ociosidade é o traço psicológico ou a falta de que derivam todas as outras formas de desvios ou crimes" (FOUCAULT, 2015, p. 43). Nesta análise, a vagabundagem não é uma predisposição psicológica, mas, sim, uma forma comum de existir dos errantes, de um grupo específico da sociedade que se mostra como uma contrassociedade.

Posteriormente, na França, a vagabundagem não era punida a contento. O vagabundo pertencia ao sistema penal pela ação de pedir mantimentos para alguém sem ter um trabaIho. Para Le Trosne, a entrada no mundo da delinquência está na vagabundagem, por não ter uma casa própria, por não ter um pedaço de terra seu, por não se determinar a conseguir um trabalho, ou seja, o crime começa quando não se tem uma situação civil estabelecida.

Segundo o pensamento de Le Trosne, não é por falta de trabalho que alguém se torna errante, pois, mesmo não tendo sustento para todos o que nunca falta é a possibilidade de trabalho, pois sempre terá trabalho suficiente para todos mesmo que o sustento não seja suficiente para a subsistência. Logo,

[...] o vagabundo não é tanto aquele a quem falta subsistência e por isso é empurrado para fora; é mais aquele que, por livre e espontânea vontade, recusa a oferta de trabalho que a terra nos faz com tanta generosidade. Não é o desemprego coagido e forçado que, aos poucos, começa a mendigar e vagar, é aquele que se recusa a trabalhar. Há, pois, uma identidade primordial a fundamental entre vagar e recusar trabalho: é nisso que, para os fisiocratas, reside o crime do vagabundo (FOUCAULT, 2015, p. 45).

Conforme Le Trosne, os vagabundos determinam as suas relações de poder de uma forma selvagem, exterior à lei com os indivíduos que estão no âmbito da sociedade civil. Desta forma, ele examina as modalidades de instauração das relações de violência, as quais representam formas particulares de delinquência. As investigações sobre a delinquência no século 17 começavam pelo desemprego para, assim, explicar a mendicidade e a delinquência, mas, para os fisiocratas, não era essa a definição correta. Os criminosos aparecem como inimigos da sociedade em razão das relações de poder violento que desempenham sobre a população e o seu posicionamento no sistema de produção, no sentido de recusar-se a trabalhar.

Le Trosne justifica o porquê de a sociedade civil não usar armas para se defender dos indivíduos que estão fora da lei ao afirmar que a população está desarmada precisamente por pertencer à sociedade civil, pois as pessoas renunciam à selvageria e ao uso livre de armas em virtude do pacto social. Pertencer a uma sociedade é rejeitar o uso de armas para se defender de uma forma imediata, uma vez que esse direito foi atribuído ao soberano. O soberano, po- 


\section{Democracia}

Humanos e

rém, defende a população com leis inadequadas, que ocorrem por diversas razões. De acordo com Le Trosne, uma é que a legislação deixa as pessoas circularem e só as prendem quando estas estendem a mão, e outra razão é que as leis fazem sua intervenção tarde demais. Para ele, as leis são demasiadamente complacentes, pois o principal das penas é a expatriação do indivíduo para outra região, fazendo com que eles comecem a vagar.

Dessa forma, o autor apresenta quatro medidas: a primeira seria a escravização, a qual faz com que o criminoso trabalhe da forma mais coercitiva possível; a segunda é que essa escravização apenas pode ser levada ao seu último resultado se for seguido por ato jurídico de colocar o criminoso fora da lei; a terceira medida é a autorização à comunidade campesina de armar-se; e a última medida é a caça e o alistamento em massa para o trabalho. Esse era um sonho de Le Trosne: um enclausuramento no local de trabalho, o qual possibilitaria aniquilar qualquer pessoa que se recusasse a trabalhar. Nesse sentido, Foucault (2015) assevera:

[...] esse texto nos conta, em sua selvageria e onirismo, aquilo que vai ocorrer meticulosamente quando as instituições e as medidas de coerção capitalistas forem instaladas. A passagem da caçada à coerção que transforma a força de trabalho em força produtiva é a condição de funcionamento do sistema penal em nossa sociedade (p. 48).

Ao se repensar esse texto da época, junto com os seus elementos e a descrição dos vagabundos, a posição que lhes foi designada na sociedade e em relação aos sistemas de produção pode-se perceber outra condição. Essas pessoas que se recusam a trabalhar, fugindo dos impostos, oneram uma quantidade de pessoas mais reduzida com a integridade da carga fiscal, que

[...] produzem filhos naturais, impõem suas cobranças de sustento, punem e festejam também são os monges itinerantes, os nobres, os agentes fiscais. Isso quer dizer que esse texto é surpreendente: nele se encontra ao mesmo tempo uma exatidão histórica total quanto aos costumes dos vagabundos e de outros personagens; é tanto a descrição dessa contrassociedade quanto a descrição da sociedade feudal da qual a burguesia queria se livrar. Lendo-se assim, o texto ganha uma violência inaudita: o que é essa regra de autodefesa campesina, senão uma espécie de convocação à insurreição? Assim, o texto diz de um lado aquilo que ocorrerá efetivamente no século XIX e, do outro, faz, de maneira codificada, uma crítica real aos resquícios de feudalismo na sociedade do século XVIII: todos devem pertencer ao Estado (FOUCAULT, 2015, p. 48).

Assim, o vagabundo e o senhor feudal integram duas instâncias de antiprodução que, na esteira de Foucault, são inimigas da sociedade; nesse sentido, é possível perceber a conjunção de uma equiparação que para o autor será fundamental, pois, a partir do momento em que a sociedade se estabelece como conjunto de relações entre sujeitos que permitem a produção, possibilitando sua maximização, estrutura-se um critério que ocasiona a designação de um inimigo da sociedade: qualquer pessoa que se oponha à regra de maximização da produção (FOUCAULT, 2015).

Foucault aduz que quando um lacaio rouba seu senhor ele é um ladrão que deve ser louvável, posto que o crime ocorre em um sentido: tira o dinheiro de quem tem demais e entrega a pessoas necessitadas. Para o autor, é essa delinquência que está em toda a sociedade, "que de certo modo segue todas as suas nervuras, flui de cima a baixo e constitui seu jogo por excelência" (2015, p. 51). A delinquência anima esse jogo, fazendo com que ele se mova, 


\section{Humanos e \\ Democracia}

porque é assim que pessoas que não têm nada se transformam em poderosos e os poderosos perdem tudo. Afinal, "delinquência é uma espécie de função social permanente" (FOUCAULT, 2015, p. 51); ela é o outro lado da história, o avesso, o externo à lei, é o jogo da sociedade, a contradição entre ser pego e não ser pego.

\section{PODER DISCIPLINAR E O SISTEMA CARCERÁRIO}

A disciplina é compreendida por Foucault (2014a) como um dispositivo de poder que não foi, em sua totalidade, inventada, mas a elaboração de seus princípios desenvolveu-se no decorrer do século 18. Elas existiram há muito tempo na Idade Média e na Antiguidade, posto que os mosteiros muito conhecidos na época eram um ótimo exemplo, onde predominava o sistema disciplinar assim como na escravidão, nas colônias espanholas, inglesas, francesas e até na legião romana.

Os mecanismos disciplinares são muito antigos, e Foucault (2014a) menciona que viviam isolados até os séculos 17 e 18, quando a disciplina foi descoberta como um poder, uma nova forma de aperfeiçoar os indivíduos. Durante a história da humanidade, muito se falou das ciências humanas, das descobertas químicas, mas nada foi dito a respeito da tecnologia que fez com que o indivíduo fosse controlado, incorporando um efeito útil para o seu corpo, resultando no seu tempo e trabalho.

Ocorreu nessa época uma distribuição espacial dos indivíduos, e Foucault (2014b) utiliza como exemplo o que aconteceu no exército no século 17 . O mesmo era composto apenas por um amontoado de pessoas, com uns mais fortes e outros mais fracos, quando surgiu, nesse cenário, o fuzil. Foi necessário, então, estudar a distribuição desses indivíduos no espaço, colocá-los em posições que teriam mais potencial, em que fosse utilizado o máximo de seus corpos, ou seja, ensinar o soldado a colocar-se no lugar onde fosse necessário, analisar o espaço, inserir seus corpos.

A disciplina tem controle sobre o desenvolvimento de uma ação e não sobre o seu resultado. Consoante Foucault (2014b), a partir do século 18 prosperou uma arte do corpo humano. Observava-se como esse corpo trabalhava, quais gestos ele fazia, qual era o gesto mais eficaz. Desse modo, surgiu o chamado contramestre, pessoa treinada para observar tudo o que o trabalhador fazia, para que seu trabalho fosse feito cada vez mais rápido, ou seja, o corpo humano como um mecanismo para o sistema de produção.

O sistema disciplinar necessita que os indivíduos sofram uma vigilância contínua. Não é suficiente olhá-los apenas uma vez e ver se estão fazendo o trabalho corretamente. É preciso uma vigilância em tempo integral;, e "submetê-los a uma perpétua pirâmide de olhares" (FOUCAULT, 2014b, p. 182). Desta maneira funciona no exército, quando não há interrupção do general-chefe por um ínfimo soldado, pois cada um vigia quem está ao seu lado: "como também os sistemas de inspeção, revistas, paradas, desfiles, etc., que permitem que cada indivíduo seja observado permanentemente" (FOUCAULT, 2014b), pois

[...] a disciplina implica um registro contínuo. Anotação do indivíduo e transferência da informação de baixo para cima, de modo que, no cume da pirâmide disciplinar, nenhum detalhe, acontecimento ou elemento disciplinar escape a esse saber. No sistema clássico, o exercício do poder era confuso, global e descontínuo. Era o poder do soberano sobre grupos constituídos por famílias, cidades, paróquias, isto é, por unidades globais, e não 


\section{Democracia}

Humanos e

um poder contínuo atuando sobre o indivíduo. A disciplina é o conjunto de técnicas pelas quais os sistemas de poder vão ter por alvo e resultado os indivíduos em sua singularidade (p. 182).

A individualização, para Foucault (2014a), tem como instrumento fundamental o exame, o qual é uma maneira de observar os indivíduos, classificá-los, julgá-los e, por consequência, utilizá-los ao máximo, fazendo com que eles se transformem em um elemento contínuo do exercício do poder. Essas características são inter-relacionadas, mas, além disso, adaptaram-se às necessidades de cada instituição de poder para realizar o mesmo objeto de adestramento. É importante ter em mente que a disciplina não é um aparelho, nem uma instituição; ela funciona como uma rede que atravessa o mundo sem fronteiras; "é o diagrama de um poder que não atua do exterior, mas trabalha o corpo dos homens, manipula seus elementos, produz seu comportamento" (FOUCAULT, 2014a, p. 21).

O poder disciplinar no início do século 17 foi conhecido como a arte do bom adestramento, como um efeito que não se apropria do corpo; pelo contrário, adestra-o, fazendo com que todas as suas forças sejam utilizadas da melhor forma possível não para o indivíduo, mas, sim, para os sistemas de produção: "Adestra as multidões confusas, móveis, inúteis de corpos e forças para uma multiplicidade de elementos individuais - pequenas células separadas, autônomas orgânicas, identidades e continuidades genéticas, segmentos combinatórios" (FOUCAULT, 1999, p. 143).

A disciplina fabrica os indivíduos; é o poder que transforma as pessoas em objetos e, ao mesmo tempo, em instrumentos de seu exercício. Funciona da forma mais calculada possível, a ponto de nem mesmo o Judiciário escapar de tal modalidade. O sucesso do poder disciplinar dá-se ao uso de três simples instrumentos: "o olhar hierárquico, a sanção normalizadora e sua combinação num procedimento que lhe é específico, o exame" (FOUCAULT, 1999, p. 143).

A vigilância hierárquica, para Foucault (2014b), é o dispositivo que obriga com apenas o olhar, induzindo efeitos e meios de coerção visíveis sobre quem se aplica. No decorrer da época clássica, foram construídos os chamados observatórios, quando foi realizada a técnica de ver e não ser visto, e esses observatórios tinham seus modelos quase iguais a de um acampamento militar, porém tinham de ser mais discretos: "No acampamento perfeito, todo o poder seria exercido somente pelo jogo de uma vigilância exata; e cada olhar seria uma peça no funcionamento global do poder" (FOUCAULT, 2014b, p. 144), na medida em que

[...] toda uma problemática se desenvolve então: a de uma arquitetura que não é mais feita simplesmente para ser vista (fausto dos palácios), ou para vigiar o espaço exterior (geometria das fortalezas), mas para permitir um controle interior, articulado e detalhado - para tornar visíveis os que nela se encontram; mais geralmente, a de uma arquitetura que seria um operador para a transformação dos indivíduos: agir sobre aquele que abriga, dar domínio sobre seu comportamento, reconduzir até eles os efeitos do poder, oferecê-los a um conhecimento, modificá-los. As pedras podem tornar dócil e conhecível (p. 169).

Graças à vigilância hierárquica, o poder disciplinar pode tornar-se realmente um sistema integrado, o qual liga o interior de uma economia ao final do exercício do mecanismo, organizando-se como um poder que é autônomo, pois, como essa vigilância recai sobre as pessoas, o seu funcionamento é do alto para baixo com fiscais permanentes: 


\section{Democracia}

Humanos e

O poder na vigilância hierárquica das disciplinas não se detém como uma coisa, não se transfere como uma propriedade; funciona como uma máquina. E se é verdade que sua organização piramidal lhe dá um "chefe", é o aparelho inteiro que produz "poder" e distribui os indivíduos nesse campo permanente e contínuo. O que permite ao poder disciplinar ser absolutamente indiscreto, pois está em toda parte e sempre alerta, pois em princípio não deixa nenhuma parte às escuras e controla continuamente os mesmos que estão encarregados de controlar; e absolutamente "discreto", pois funciona permanentemente e em grande parte em silêncio. A disciplina faz "funcionar" um poder relacional que se autossustenta [sic] por seus próprios mecanismos e substitui o brilho das manifestações pelo jogo ininterrupto dos olhares calculados. Graças às técnicas de vigilância, a "física" do poder, o domínio sobre o corpo se efetua segundo as leis da ótica e da mecânica, segundo um jogo de espaços, de linhas, de telas, de feixes, de graus, e sem recurso, pelo menos em princípio, ao excesso, à força, à violência. Poder que é em aparência ainda menos "corporal" por ser mais sabiamente "físico" (FOUCAULT, 2014b, p. 174).

A sanção normalizadora, de acordo com Foucault (2014b), é essencial em qualquer sistema disciplinar; é uma espécie de pequeno mecanismo penal; ocupa um espaço que escapa às normas; é uma maneira de qualificar ou recriminar um comportamento. A disciplina, porém, traz uma maneira própria de punir; "o que pertence à penalidade disciplinar é a inobservância, tudo que está inadequado à regra, tudo o que se afasta dela, os desvios" (FOUCAULT, 1999 , p. 149). Ou seja, o poder disciplinar tem como regra punir tudo aquilo que seja um descumprimento às normas.

Nesse contexto, o castigo no sistema disciplinar tem como objetivo diminuir os desvios, diferente das punições do Judiciário da época (multas, açoite, masmorra), pois, nos sistemas disciplinares, a punição era com o aprendizado, sendo ele intensificado, multiplicado e, muitas vezes, repetido como forma de punição pela falta/desvio cometido.

A punição na disciplina é uma relação do bem e do mal, da gratificação e da sanção. Foi o que a sanção normalizadora fez: separou os indivíduos bons e maus; "através dessa microeconomia de uma penalidade perpétua, opera-se uma diferenciação que não é a dos atos, mas dos próprios indivíduos, de sua natureza, de suas virtualidades, de seu nível ou valor" (FOUCAULT, 1999, p. 151).

Os indivíduos são divididos e demarcados dentro do corpo social, com o objetivo de "marcar os desvios, hierarquizar as qualidades, as competências e as aptidões; mas também castigar e recompensar" (FOUCAULT, 1999, p. 151). O único modo de recompensa na disciplina é a promoção de lugares na sociedade, e a punição é o rebaixamento desses lugares. Em suma, as punições, no sistema disciplinar, põem em prática cinco operações diferenciadas,

[...] relacionar os atos, os desempenhos, os comportamentos singulares e um conjunto, que é ao mesmo tempo campo de comparação, espaço de diferenciação e princípio de uma regra a seguir. Diferenciar os indivíduos em relação uns aos outros e em função dessa regra de conjunto - que se deve fazer funcionar como base mínima, como média a respeitar ou como o ótimo de que se deve chegar perto. Medir em termos quantitativos e hierarquizar em termos de valor as capacidades, o nível, a "natureza" dos indivíduos. Fazer funcionar, através dessa medida "valorizadora", a coação de uma conformidade a realizar. Enfim traçar o limite que definirá a diferença em relação a todas as diferenças, a fronteira externa do anormal (a "classe vergonhosa" da Escola Militar). A penalidade 


\section{Democracia}

Humanos e

perpétua que atravessa todos os pontos e controla todos os instantes das instituições disciplinares compara, diferencia, hierarquiza, homogeniza, exclui. Em uma palavra, ela normaliza (FOUCAULT, 2014b, p. 179-180).

Em 1793, Bentham configurou o projeto do Panopticon, que é a imagem arquitetônica dessa composição do poder disciplinar na Europa. Esse novo dispositivo organizava as unidades fazendo com que se pudesse ver sem parar, e que todos os indivíduos fossem reconhecidos imediatamente, ou seja, a luz e o olhar de um guarda seriam melhores de capturar do que como era antes nas sombras de uma masmorra; tudo ficaria visível. Pode-se ver esse sistema em todas as instituições da sociedade, como nas escolas, fábricas, quartéis e nas prisões. De acordo com Foucualt em Microfísica do Poder (2015), o efeito desse projeto arquitetônico nos detentos é de uma espécie de vigiar permanente, ou seja, faz com que o poder disciplinar opere com a sua máxima potência. Esse projeto de Bentham seria uma máquina que sustenta as relações de poder, onde os próprios detentos, nos seus micropoderes e microespaços, conseguem vigiar uns aos outros.

A prisão surgiu fora do aparelho Judiciário; foi nesse processo em que se começou a adequação dos indivíduos, a classificá-los, formando um aparelho completo de observações de anotações, tirando deles o máximo de tempo e de suas forças, mantendo-os em observação contínua com o objetivo de torná-los úteis e dóceis para as instituições. Dessa maneira, criou-se a instituição-prisão, antes mesmo de a lei defini-la como meio de punição:

Na passagem dos dois séculos, uma nova legislação define o poder de punir como uma função geral da sociedade que é exercida da mesma maneira sobre todos os seus membros, e na qual cada um deles é igualmente representado; mas, ao fazer da detenção a pena por excelência, ela introduz processos de dominação característicos de um tipo particular de poder. Uma justiça que se diz "igual", um aparelho judiciário que se pretende "autônomo", mas que é investido pelas assimetrias das sujeições disciplinares, tal é a conjunção do nascimento da prisão, "pena das sociedades civilizadas" (p. 223-224).

Até o fim do século 18 a prisão não foi considerada um castigo dentro do sistema penal. Essa introdução é datada do final do século 18, segundo o Código Criminal de 1767, mas demorou mais um tempo para ser instituída em outros países. Consoante Foucault (2014b), na França ainda foi necessário esperar até 1791 para que fosse formulado o princípio do encarceramento como punição.

A cadeia "desde o início foi uma 'detenção legal' encarregada de um suplemento corretivo, ou ainda uma empresa de modificação dos indivíduos que a privação de liberdade permite fazer funcionar no sistema legal" (FOUCAULT, 1999, p. 196). Nada disso, entretanto, aconteceu. Desde 1820 já era verificado que a prisão, em vez de modificar os criminosos, só fazia com que piorassem.

Essa organização era habitualmente vista como um depósito de criminosos, onde as pessoas consideradas importunas eram colocadas. Nesse cenário foi constatada a necessidade de uma reforma das prisões, fazendo com que se tornassem um dispositivo de transformação de indivíduos, mas "o fracasso foi imediato e registrado quase ao mesmo tempo em que o próprio projeto" (FOUCAULT, 2014b, p. 216). De acordo com o autor, 


\section{Democracia}

Humanos e

[...] a prisão deve ser um aparelho disciplinar exaustivo. Em vários sentidos: deve tomar a seu cargo todos os aspectos do indivíduo, seu treinamento físico, sua aptidão para o trabalho, seu comportamento cotidiano, sua atitude moral, suas disposições; a prisão, muito mais que a escola, a oficina ou o exército, que implicam sempre numa certa especialização, é "onidisciplinar". Além disso, a prisão é sem exterior nem lacuna; não se interrompe, a não ser depois de terminada totalmente sua tarefa; sua ação sobre o indivíduo deve ser ininterrupta: disciplina incessante. Enfim, ela dá um poder quase total sobre os detentos; tem seus mecanismos internos de repressão e de castigo: disciplina despótica. Leva à mais forte intensidade todos os processos que encontramos nos outros dispositivos de disciplina. Ela tem que ser a maquinaria mais potente para impor uma nova forma ao indivíduo pervertido; seu modo de ação é a coação de uma educação total (p. 228).

O sistema, que hoje é conhecido como carcerário, causou uma grande ruptura no aspecto sociocultural do indivíduo. Segundo Foucault (2014a), após o indivíduo adentrar na rede de poderes dessa instituição, passou a ser visto como sujeito não merecedor de direitos, restando-Ihe apenas a privação do convívio em sociedade. A utopia da ressocialização que, em tese, é um dos objetivos desse sistema, foi substituída pela produção da delinquência.

Nesse sentido, pode-se falar de uma série de excessos do encarceramento, tanto no sistema carcerário quanto no Judiciário, observáveis desde o seu nascimento. É possível notar isso nas violências desnecessárias dos guardas para com os detentos, sem falar do despotismo e dos privilégios encontrados nas quatro paredes de uma prisão. De acordo com Foucault (2014a), porém, a sua essência está no clamor de que a prisão seja "útil", sob o fato de que a privação de liberdade realiza uma transformação nos sujeitos.

Para essa intervenção o aparelho carcerário investigou três grandes esquemas: "o esquema político-moral do isolamento individual e da hierarquia; o modelo econômico da força aplicada e um trabalho obrigatório; o modelo técnico-médico da cura e da normalização" (FOUCAULT, 2014a, p. 241). A fronteira em que a prisão transpassa a detenção é preenchida por técnicas disciplinares, e é esse acréscimo da disciplina com o Judiciário que é intitulado de penitenciário.

Nesse ínterim, Foucault (2014a) entende que o juiz surgiu como aplicador da pena e a prisão como local de execução da pena e, agora, ao mesmo tempo, local de observação dos sujeitos punidos, para que se conheçam cada um, seus comportamentos, suas melhorias ou pioras, posto que a prisão deve ser configurada como um local de formação de um saber clínico sobre o delinquente.

\section{CONSIDERAÇÕES FINAIS}

No sistema penitenciário a prisão não tem apenas de aplicar as decisões dos juízes, mas também inserir permanentemente no detento um saber que vai transformar uma medida penal em uma operação penitenciária, fazendo da pena sofrida pelo detento uma maneira de modificá-lo para ser útil à sociedade, ou seja, nessa nova maneira de pensar, segundo Foucault (2014b), o delinquente deve ser o indivíduo a ser conhecido. O aparelho penitenciário tira das mãos da justiça o indivíduo condenado e não se deve aplicar a ele uma infração, mas, sim, algo que difere das definições acerca do infrator, que foi observado anteriormente apenas em uma tecnologia corretiva: "Esse outro personagem, que o aparelho penitenciário coloca no lugar do infrator condenado, é o delinquente" (p. 245). 


\section{Democracia}

Humanos e

A diferença entre delinquente e infrator não está no ato ilícito que cometeu, mas na sua vida e no que o caracteriza. A penitenciária, nesse momento, passa a ser um mecanismo de reeducação para montar a vida do delinquente. Observando o criminoso em 1838, pode-se compreender que

[...] deve remontar não só às circunstâncias, mas às causas de seu crime; procurá-las na história de sua vida, sob o triplo ponto de vista da organização, da posição social e da educação, para conhecer e constatar as inclinações perigosas da primeira, as predisposições nocivas da segunda e os maus antecedentes da terceira. Esse inquérito biográfico é parte essencial da instrução judiciária para a classificação das penalidades antes de se tornar uma condição do sistema penitenciário para a classificação das moralidades. Deve acompanhar o detento do tribunal à prisão, onde o ofício do diretor é não somente recoIher, mas também completar, controlar e retificar seus elementos no decorrer da detenção (LUCAS, Ch, 1838, p. 440-442 apud FOUCAULT, 2014b).

Nesse sentido, o criminoso pertence a uma nova tipologia, que é, ao mesmo tempo, natural e desviante, pois a delinquência, conforme Foucault (2014b), é vista como um desvio patológico de toda a espécie humana, o qual possibilita o surgimento de um novo saber que viabilizou a criminologia, propiciando um conhecimento positivo dos delinquentes, o que difere completamente da concepção jurídica das infrações.

Correlacionado ao sistema penitenciário, temos

[...] o delinquente, unidade biográfica, núcleo de "periculosidade", representante de um tipo de anomalia. E se é verdade que à detenção privativa de liberdade que o direito definiria a prisão acrescentou o "suplemento" do penitenciário, este por sua vez introduziu um personagem a mais, que se meteu entre aquele que a lei condena e aquela que executa essa lei. Onde desapareceu o corpo marcado, recortado, queimado, aniquilado do suplício, apareceu o corpo do prisioneiro, acompanhado pela individualidade do "delinquente", pela pequena alma do criminoso, que o próprio aparelho do castigo fabricou como ponto de aplicação do poder de punir e como objetivo do que ainda hoje se chama a ciência penitenciária. Dizem que a prisão fabrica delinquentes; é verdade que ela leva de novo, quase fatalmente, diante dos tribunais aqueles que lhe foram confiados. Mas ela os fabrica no outro sentido de que ela introduziu no jogo da lei e da infração, do juiz e do infrator, do condenado e do carrasco, a realidade incorpórea da delinquência que os liga uns aos outros e, há um século e meio, os paga todos juntos na mesma armadilha (p. 248).

Um modelo essencial da utilização da delinquência ocorreu no século 19 , quando os operários sentiam um ódio gigantesco dos delinquentes. Esses sujeitos eram usados contra os operários nas políticas sociais para impedir que furassem greves. Os trabalhadores temiam que houvesse uma concorrência, que os malfeitores fizessem o mesmo trabalho por um preço mais baixo que o deles, arruinando os seus salários. Foucault (2014b) coloca em jogo uma hipótese importante: talvez esse ódio entre as duas classes tenha sido calculadamente pensado para que houvesse o efetivo funcionamento do sistema.

Foucault (2014b) aponta outra utilização ocorrida no século 19 com as campanhas de cristianização, que surgiram pregando a moralidade como forma de proteger as riquezas conquistadas com o suor do trabalho dos operários. Foi necessária uma constituição da moral, para, assim, separar os operários dos delinquentes, mostrando nitidamente o grupo de delin- 


\section{Democracia}

Humanos e

quentes como sendo perigosos para a sociedade, não apenas para os ricos, mas, agora, para os pobres também, "mostrando-os carregados de todos os vícios e responsáveis pelos maiores perigos" (p. 218).

A chamada literatura policial também foi responsável pela má-fama dos delinquentes, tanto que Foucault (2014b) menciona as páginas policiais onde eram encontradas narrativas e textos horríveis sobre os delinquentes. A partir de então, a prisão passou a ser vista como um dispositivo de recrutamento de delinquentes. No momento em que a pessoa entrava na prisão o mecanismo era acionado, e, quando saía, a delinquência era a única alternativa:

Em lugar de haver, como no século XVIII, bandos nômades que percorriam o campo e que frequentemente eram de grande selvageria, existe a partir daquele momento, este meio delinquente bem fechado, bem infiltrado pela polícia, meio essencialmente urbano e que é de uma utilidade política e econômica não negligenciável (p. 219).

De acordo com Foucault (2014b), no período compreendido entre os anos 1835 e 1840 ficou explícito que a prisão não procurava reeducar os delinquentes, tampouco torná-los honestos, mas, sim, apenas inseri-los em um lugar bem-definido, onde ficassem amontoados, rotulando-os para que posteriormente fossem considerados uma arma com fins econômicos e políticos. O plano, então, era não lhes ensinar absolutamente nada, para que quando saíssem da prisão não tivessem o que fazer de sua vida. Desse modo, o trabalho penal, que até então era considerado útil, serve como estratégia.

Fazem parte desse cenário o cinismo e a inteligência da burguesia do século 19, que pensou esse emaranhado de poderes em torno do delinquente. Consoante Foucault (2014b), a delinquência foi um sonho realizado no século 18. É impossível imaginar uma sociedade sem delinquência; sem ela nem a polícia teria motivo de existir. Nesse norte, "a delinquência era por demais útil para que se pudesse sonhar com algo tão tolo e perigoso como uma sociedade sem delinquência. Sem delinquência não há polícia" (p. 225).

O que faz com que a população tolere a polícia é justamente a existência de criminosos. Esse é o único jeito de justificá-la, pois "[...] essa instituição tão recente e tão pesada que é a polícia não justifica senão por isso. Aceitamos entre nós essa gente de uniforme, armada, enquanto nós não temos esse direito, que nos pede documentos, que vem rondar nossas portas" (FOUCAULT, 2014b, p. 225).

Não houve no decorrer da história prisional um cronograma lógico de seus acontecimentos, apenas foi estabelecida a detenção, logo após o registro do seu desastre, tentativas de reforma e a constatação de seus sucessos ou fracassos. Afinal, "as prisões não diminuem a taxa de criminalidade: pode-se aumentá-las, multiplicá-las ou transformá-las, a quantidade de crimes e de criminosos permanece estável, ou, ainda pior, aumenta" (FOUCAULT, 1999, p. 221).

Comprovou-se, também, que a detenção causa reincidência. Após sair da prisão são grandes as proporções de retornar para ela. A maioria dos carcerários já foram detentos anteriormente. Foucault (2014b) aduz que o fracasso da prisão serviu como uma modalidade de gerir as ilegalidades, ou seja, a prisão não serviu para punição e, sim, para adestramento, porque toda a gestão das ilegalidades faz parte dos mecanismos de poder: 


\section{Democracia}

Humanos e

Essa produção da delinquência e seu investimento pelo aparelho penal devem ser tomados pelo que são: não resultados definitivos, mas táticas que se deslocam na medida em que nunca atingem inteiramente seu objetivo. $O$ corte entre sua delinquência e as outras ilegalidades, o fato de que ela se tenha voltado contra elas, sua colonização pelas ilegalidades dominantes - outros tantos efeitos que aparecem claramente na maneira como funciona o sistema polícia-prisão - não cessaram, entretanto, de encontrar resistências; suscitaram lutas e provocaram reações (FOUCAULT, 1999, p. 236).

Desde a Idade Média a burguesia construiu três formas de controlar a máquina jurídica do Estado. Em primeiro lugar, eles apossaram-se dos cargos do aparato Judiciário, posteriormente foi necessário reger esses cargos, e por último, articular a prática de ilegalidade para que ela mesma pudesse também praticar, fazendo com que ocorresse o desequilíbrio do legalismo. O ilegalismo burguês, para Foucault (2015), não estava mais conseguindo conviver com o ilegalismo da população; então, foi a maneira mais inteligente de entrar para o Poder Judiciário e cometer as suas ilegalidades lá dentro.

A partir disso, segundo Foucault (2015), surgiram algumas consequências: a imputação de todas as formas de ilegalidades e daquele que praticava a ilegalidade, considerado agora inimigo social, diferente do delinquente no século 18 , que não era considerado inimigo social porque fazia com que o sistema funcionasse; pode-se notar que o criminoso, como o indivíduo que rompe com o contrato social, foi reintegrado a essa definição da burguesia; outra decorrência foi a infiltração de vigilantes da burguesia no meio delinquente, com o objetivo de punir esses criminosos.

De acordo com Foucault (2015), desenvolveu-se nesse cenário, entre as classes da burguesia e o proletariado, o sistema penitenciário com o objetivo de ser um mecanismo de controle e preservação das relações de produção. O que a burguesia queria não era simplesmente eliminar a delinquência, mas organizar o mundo da delinquência utilizando dois instrumentos: o delinquente como inimigo social, não aquele que vai contra a lei, mas o indivíduo que está em guerra com cada membro da sociedade, e o instrumento prático mais conhecido: a prisão.

A reincidência foi percebida imediatamente, fazendo com que a prisão fosse entendida não somente como o lugar de enclausuramento de delinquentes, mas, também, como um sistema independente, no qual a delinquência seria confinada como um fenômeno social. Foucault (2015) entende que a conjunção entre a definição jurídico-penal de infrator como inimigo social e a definição do indivíduo a ser transformado, verifica-se em vários discursos que transformam a aplicação do sistema penitenciário do século 19 teoricamente aceitáveis.

Essa conjunção afirma, primeiramente, que todos os ilegalismos fazem parte, de maneira preferencial, de uma única classe social - a dos operários -, e em segundo lugar indica que os ilegalismos são um efeito dessa classe social, pois, para Foucault (2015), a mesma não está introduzida na sociedade, e, por último, o fato de os trabalhadores não concordarem com o pacto social é considerado uma espécie de delinquência primária, pois é uma parte da população que está mais próxima dos instintos primitivos da natureza. Esse atributo dado à classe dos operários como o instrumento privilegiado da transformação que o penitenciário pode fazer para a inclusão no pacto social, tornou aceitável a ordenação do sistema penal e penitenciário. 


\section{Democracia}

Humanos e

Um pouco mais adiante, com relação ao modo que as penas deveriam funcionar, percebe-se que elas eram diferentes das do século 18 e também de como os teóricos do mesmo século gostariam. No século 19 propõem-se uma pena que deveria agir sobre o próprio indivíduo para reeducá-lo:

Há, portanto, uma espécie de dualidade, essencial ao sistema penal como um todo: por um lado, o desenvolvimento da teoria de Beccaria, um discurso da penalidade pura, que só conhece a positividade da lei, e não a imoralidade do crime, só a universalidade da lei, e não a moralização dos indivíduos, só a inevitabilidade da lei, e não a correção dos indivíduos; por outro, misturada aos textos e às instituições, uma espécie de pesquisa que pretende corrigir, regenerar o indivíduo. Esses dois elementos são fundamentais no sistema penal, e, no ponto de articulação de ambos, está o lugar onde vai ocorrer o discurso da transcrição de um para o outro, uma espécie de discurso psicojurídico cuja função é retranscrever um termos de correção, regeneração e cura os elementos jurídicos da penalidade e, inversamente, recodificar as noções morais como categorias penais (FOUCAULT, 2015, p. 163-164).

Esse é um discurso que traz em si a criminologia, aquela que, consoante Foucault (2015), possibilita, de acordo com uma fala criminológica, reproduzir um saber jurídico-médico sobre aquele que a teoria penal chamou de inimigo social. Também possibilitou retratar a punição como uma readaptação social. Surgiu na criminologia uma espécie de tendência à delinquência. $O$ indivíduo que tinha uma grande periculosidade social foi a maneira encontrada de codificar, de forma penal, uma categoria psicológica que não é de competência jurídica.

No entendimento de Foucault (2015), foi nesse momento que a criminologia solicitou que a punição não fosse de acordo com o delito e nem do que o sujeito era no momento do crime, pois, uma vez que a punição era considerada uma cura, a mesma só poderia terminar quando se tivesse certeza que a cura tivera sido encontrada:

O objeto das discussões de médicos e juízes por volta de 1815-1850, noção curiosa porque os médicos definem como monomania homicida uma doença que consiste em não apresentar nenhum outro sintoma além do de matar alguém. A sintomatologia se reduz àquilo que é codificado penalmente como homicídio. Tem-se aí um grau mais simples da transcrição. Crime nada mais é que doença. E, inversamente, a menos que o crime seja determinado por alguma razão designável, com a noção de monomania começa a elaborar-se essa transcrição do jurídico no médico, que vai dar ensejo à enorme proliferação do discurso criminológico (FOUCAULT, 2015, p. 164-165).

Essa mudança do sistema penal não diz respeito apenas à história dos corpos, quando a medicina entrou trazendo um conhecimento da normalidade dos corpos, ocupando o sistema penal e afirmando que a pena deveria ter como finalidade a cura, mas, sim, e principalmente, de uma história das relações de poder do político com os corpos. Essa opressão sob o sujeito, segundo Foucault (2015), o controle e a dominação que ele conseguia exercer, seriam necessários para criar uma análise e demonstrar como ele foi amplamente modificado em relação às suas formas anteriores datadas do século 19, juntamente com a criação das estruturas do poder estatal:

Uma nova óptica, para começar: órgão de vigilância generalizada e constante; tudo deve ser observado, visto, transmitido: organização de uma política; instituição de um sistema de arquivos (com fichas individuais); estabelecimento de um panoptismo. Uma nova me- 


\section{Democracia}

Humanos e

cânima: isolamento e reagrupamento dos indivíduos; localização dos corpos; utilização ideal das forças; controle e melhoria do rendimento; em suma, estabelecimento de toda uma disciplina da vida, do tempo, das energias. Uma nova fisiologia: definição das normas, exclusão e rejeição do que não se conforma a elas, mecanismo de restabelecimento de tais normas por meio de intervenções corretivas que, de maneira ambígua, são terapêuticas e punitivas (FOUCAULT, 2015, p. 238-239).

Nesse contexto, a delinquência exerce um papel de grande importância. É necessário entender, no entanto, que não se trata de delinquentes como uma espécie de sujeitos externos à sociedade, que recebem toda a opressão penal, e sim que é um "sistema acoplado penalidade-delinquente" (FOUCAULT, 2015, p. 239). O sistema penal com todos os seus mecanismos de controle, e principalmente a prisão na sua essência, "fabrica uma categoria de indivíduos que formam um circuito com ela: a prisão não corrige; ela chama incessantemente os mesmos de volta" (FOUCAULT, 2015, p. 239). Ou seja, ela cria uma parte da população como sendo marginalizada, que é usada como instrumento de opressão para os ilegalismos que a burguesia não conseguiu tolerar.

Essa repreensão realiza-se de três maneiras sobre os ilegalismos com a ajuda da delinquência: transformando aos poucos as ilegalidades em infrações penais, "em virtude de todo um jogo de exclusões e punições parapenais" (FOUCAULT, 2015, p. 239), ou melhor, leva o indivíduo ao jogo das indisciplinas; alista uma grande quantidade de delinquentes, policiais, como um instrumento de vigilância das irregularidades; e conduz a população a um entendimento de que é mais importante vigiar os criminosos; "é sempre mais fácil um pobre roubar que um rico" (FOUCAULT, 2015, p. 239).

Diante disso, Foucault (2015) conceitua que a prisão tem o privilégio de produzir a delinquência e que foi e ainda é um instrumento de opressão social, direcionada, principalmente, a uma classe específica da sociedade: a dos operários. Ela é um pedaço do quebra-cabeça do poder exercido sobre os corpos há muitos séculos; é um poder que desencadeou um grandioso saber sobre a psicologia do sujeito; o saber sobre quem é o delinquente fora do crime que cometeu.

\section{REFERÊNCIAS}

FOUCAULT, Michel. A sociedade punitiva: curso no Collège de France (1972-1973). Tradução Ivone C. Benedetti. São Paulo: Editora Martins Fontes, 2015.

FOUCAULT, Michel. Microfísica do poder. 28. ed. Rio de Janeiro: Paz e Terra, 2014a.

FOUCAULT, Michel. Em defesa da sociedade. São Paulo: Martins Fontes, 2002.

FOUCAULT, Michel. Vigiar e punir: nascimento da prisão. 20. ed. Petrópolis: Vozes, 1999.

FOUCAULT, Michel. Vigiar e punir: nascimento da prisão. 3. ed. Petrópolis: Vozes, 1990.

FOUCAULT, Michel. Vigiar e punir: nascimento da prisão. Tradução Raquel Ramalhete. 42. ed. Petrópolis: Vozes, 2014b.

FOUCAULT, Michel. História da Sexualidade 1: a vontade de saber. Tradução Maria Thereza da Costa Albuquerque e J. Guilhon Albuquerque. 1. ed. São Paulo: Paz e Terra, 2014c.

FOUCAULT, Michel. Vigiar e punir: história da violência nas prisões. Tradução Ligia M. Pondé Vassalo. Petrópolis: Vozes, 1987.

LÉVI-STRAUSS, Claude. Tristes trópicos. São Paulo: Companhia das Letras, 1955.

MACHADO, Roberto. Ciência e saber: trajetória da arqueologia de Foucault. Rio de Janeiro: Graal, 1988. 